\title{
PENGARUH PEMAKAIAN HYDROCARBON CRACK SYSTEM (HCS) TERHADAP PERFORMA SEPEDA MOTOR SUPRA X 125 TAHUN 2009
}

\author{
Jusnita $^{1 *}$, Hasbi $^{2}$ \\ Jurusan Mesin Otomotif Fakultas Teknik Universitas Muhammadiyah Riau \\ Jalan Tuanku Tambusai Ujung, Kecamatan Tampan, Kelurahan Delima, Kota Pekanbaru, Riau 28291 \\ Email: jusnita@umri.ac.id
}

\begin{abstract}
Motor vehicles in Indonesia which are the largest source of exhaust emissions are motorbikes. This is the lack of attention of motorized vehicle users with high engine compression ratios, which tend to choose to refuel their motorbikes with premium which is cheaper but has a low octane number. This of course will cause problems with incomplete combustion. The resulting effect is to increase air pollutants. To overcome the above problems is by using the Hydrocarbon Crack System (HCS), HCS works to improve the combustion process, so that it can reduce the levels of vehicle exhaust emissions. The purpose of this study is to see the effect of the use of the Hydrocarbon Crack System (HCS) on the performance and content of the resulting exhaust emissions. Based on the research results, it was found that the use of HCS on a Honda Supra X 125 motorcycle could reduce CO gas emissions by $40 \%$. For HC gas emissions, the use of $\mathrm{HCS}$ can reduce $\mathrm{HC}$ gas emissions by $37 \%$, while for $\mathrm{CO} 2$ exhaust emissions, the use of HCS can increase $\mathrm{CO} 2$ emissions by $12.98 \%$.
\end{abstract}

Keywords: Torque, Power, Hydrocarbon Crack System (HCS), exhaust emissions

\begin{abstract}
Kendaraan bermotor di Indonesia yang menjadi sumber emisi gas buang terbesar adalah sepeda motor. Ini merupakan kurangnya perhatian pengguna kendaraan bermotor dengan perbandingan kompresi mesin kendaraan yang tinggi cenderung memilih mengisi bahan bakar sepeda motornya dengan premium yang harganya lebih murah namun memiliki angka oktan yang rendah. Hal ini tentu akan menimbulkan masalah terhadap pembakaran yang tidak sempurna. Efek yang ditimbulkan adalah menyebabkan meningkatnya polutan pencemaran udara. Untuk mengatasi permasalahan diatas adalah dengan cara menggunakan Hydrocarbon Crack System (HCS), HCS bekerja untuk menyempurnakan proses pembakaran, sehingga dapat menurunkan kadar emisi gas buang kendaraan. Tujuan dari penelitian ini melihat pengaruh penggunaan Hydrocarbon Crack System (HCS) terhadap performa dan kandungan emisi gas buang yang dihasilkan. Berdasarkan hasil penelitian diperoleh bahwa penggunaan HCS pada sepeda motor Honda Supra X 125 dapat menurunkan emisi gas CO sebesar $40 \%$. Untuk emisi gas HC penggunaan HCS dapat menurunkan emisi gas $\mathrm{HC}$ sebesar 37\%,sedangkan untuk emisi gas buang $\mathrm{CO} 2$ penggunaan HCS dapat meningkatkan emisi gas $\mathrm{CO} 2$ sebesar $12.98 \%$.
\end{abstract}

Kata kunci: Torsi, Daya, Hydrocarbon Crack System (HCS), emisi gas buang 


\section{Pendahuluan}

Salah satu alat tansportasi sehari-hari yaitu sepeda motor. Performa sepeda motor dipengaruhi oleh kualitas bahan bakar dan sistem bahan bakar. Pengguna sepeda motor sering kurang menyadari bahwa spesifikasi rinci sangat menentukan gerak dan laju kendaraannya. Penggunaan bahan bakar yang kualitas kurang baik dapat berakibat pada turunnya performa sepeda motor. Pemilihan bahan bakar disesuaikan dengan spesifikasi pada sepeda motor. Semakin tinggi perbandingan campuran bahan bakar dan udara pada sepeda motor, maka harus menggunakan bahan bakar yang berkualitas baik. Kualitas bahan bakar ditunjukkan dengan angka oktan.

Pemakaian sepeda motor tentunya tidak lepas dari jenis bahan bakar yang digunakan untuk memperoleh performa mesin yang optimal sperti daya, torsi dan komsumsi bahan bakar. Sistem pembakaran adalah proses yang terjadi di dalam silinder selama pembakaran. Hal ini terjadi dengan adanya peningkatan suhu temperatur dan tekanan di dalam silinder. Sistem pembakaran terjadi karena bercampurnya bahan bakar dan udara dengan ditambah percikan bunga api dari busi. Apabila proses pembakaran berjalan dengan sempurna, maka diperoleh pembakaran yang prima. Saat ini uap hidrokarbon juga merupakan emisi yang dihasilkan dari setiap kendaraan bermotor, akan tetapi uap hidrokarbon dapat menjadi solusi alternatif untuk meningkatkan kinerja mesin, hidrokarbon dari penguapan bahan bakar dapat diuraikan (crack) menjadi hidrogen $\left(\mathrm{H}_{2}\right)$ dan karbon $(\mathrm{C})$ dengan menggunakan pipa katalis, dipasang pada bagian mesin yang panas seperti blok mesin dan knalpot (Ikhsan dkk, 2016).

Sistem ini disebut juga Hydrocarbon Crack System (HCS), hidrogen yang dihasilkan masuk dalam proses pembakaran kemudian pembakaran akan berlangsung lebih sempurna karena hidrogen memiliki oktan yang tinggi senilai 130 dengan kalor terendah yang dihasilkan $119.93 \mathrm{MJ} / \mathrm{kg}$ (Hairuddin dkk, 2014). Hidrogen ini akan menjadi suplemen saat proses pembakaran sehingga secara otomatis akan mengurangi emisi gas buang.

\section{Metodologi}

Metodologi yang digunakan dalam penelitian ini metode pengujian alat Hidrocarbon Crack System (HCS) yang digunakan pada sepeda motor supra X 125 . Pengujian menggunakan alat uji dynojet. Untuk mendapatkan data yang akurat dengan dilakukan pengujian delapan belas kali dengan rincian enam kali pengujian kecepatan, enam kali pengujian torsi dan enam kali pengujian daya .

\section{Hasil dan Pembahasan}

Hasil perbandingan pengujian menggunakan Hidrocarbon Crack System dengan alat uji dynojet untuk mendapatkan nilai torsi maksimum dan daya maksimum, seperti pada tabel dibawah ini;

Tabel 1. Nilai Torsi Maksimum

\begin{tabular}{cccc}
\hline $\begin{array}{c}\text { Torsi Maks } \\
(\mathrm{NM})\end{array}$ & RPM & $\begin{array}{c}\text { NTorsi } \\
\text { Maks } \\
(\mathrm{Nm})\end{array}$ & Rpm \\
\hline 10.33 & 4340 & 9.61 & 4950 \\
\hline 10.65 & 4410 & 9.59 & 5150 \\
\hline 9.43 & 5060 & 9.74 & 4150 \\
\hline
\end{tabular}

Dari data diatas didapat nilai torsi maksimum yang tidak menggunakan Hidrocarbon Crack System adalah 10.13 $\mathrm{Nm}$ pada $\mathrm{rpm}$ 4.603. Untuk nilai daya maksimum seperti pada tabel dibawah ini;

Tabel 2. Nilai Daya Maksimum

\begin{tabular}{cccc}
\hline $\begin{array}{c}\text { Nilai Daya } \\
\text { (Watt) }\end{array}$ & RPM & $\begin{array}{c}\text { Nilai Daya } \\
\text { (HP) }\end{array}$ & RPM \\
\hline 5795.73 & 6970 & 6075.21 & 7250 \\
\hline 5928.11 & 6770 & 6104.63 & 7100 \\
\hline 5957.53 & 6910 & 6119.34 & 7020 \\
\hline
\end{tabular}

Nilai daya rata-rata maksimum yang tidak menggunakan Hidrocarbon Crack System adalah 5893,79 HP dengan rpm 6883. Sedangkan yang menggunakan Hidrocarbon Crack System nilai daya 
maksimumnya adalah pada RPM 7,123.

Tabel 3. Torsi vs Daya $m$

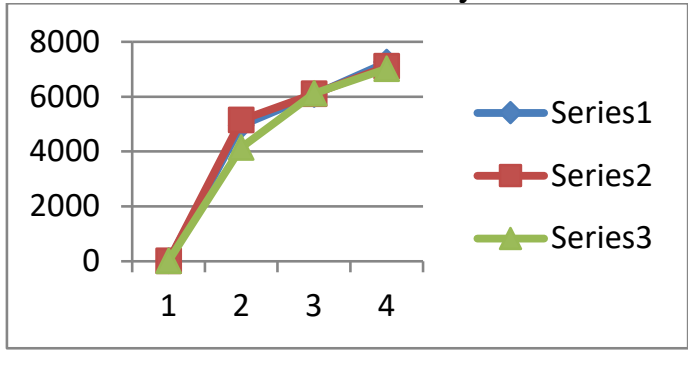

Maka dapat disimpulkan bahwa Hidrocarbon Crack System mempengaruhi daya dengan selisih nilai 20,594 HP.

Hasil pengujian bahan bakar yang tidak menggunakan alat Hidrocarbon Crack System jarak tempuh 75,8 km/liter dengan kecepatan rata-rata 60-70 $\mathrm{km} /$ menit. Sedangkan menggunakan alat Hidrocarbon Crack System dengan jarak tempuh $85,8 \mathrm{~km} /$ liter pada kecepatan ratarata $60-70 \mathrm{~km} /$ menit. Maka dapat diambil kesimpulan bahwa selisih jarak tempuh untuk adalah $10 \mathrm{~km} /$ liter dengan kecepatan rata-rata $60-70 \mathrm{~km} / \mathrm{jam}$ pada sepeda motor yang menggunakan alat Hidrocarbon Crack System.

Pengujian emisi gas buang menggunakan alat uji HCCO analyzer. Hasil pengujian emisi gas buang pada putaran mesin 2000 rpm tidak menggunakan alat HCS datanya seperti pada gambar dibawah ini:

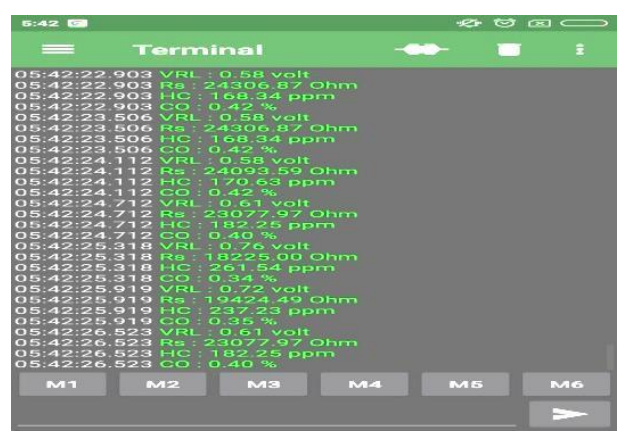

Gambar 1. Data Pengujian Emisi Gas Buang

Dari data hasil pengujian emisi gas buang yang tidak menggunakan Hidrocarbon Crack System untuk nilai CO
$0.40 \%$ dan nilai HC 182.25 ppm. Dari hasil pengujian emisi gas buang pada putaran mesin $2000 \mathrm{rpm}$ menggunakan alat HCS datanya seperti pada gambar dibawah ini:

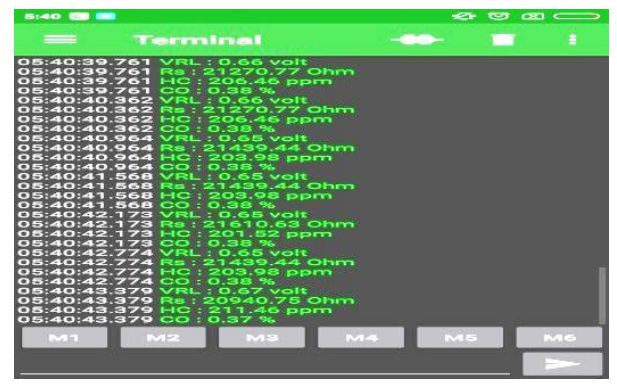

Gambar 2. Data pengujian Emisi Gas Buang menggunakan HCS

Dari data diatas hasil pengujian emisi gas buang untuk nilai CO $0.37 \%$ dan nilai HC 211.46 ppm ppm.

Table 4. Perbandingan emisi gas buang

\begin{tabular}{|c|c|c|}
\hline $\mathrm{CO}$ & $\mathrm{HC}$ & Ket \\
\hline $0.37 \%$ & $211.4 \mathrm{ppm}$ & Pakai alat HCS \\
\hline $0.40 \%$ & $182.25 \mathrm{ppm}$ & $\begin{array}{c}\text { Tidak pakai alat } \\
\text { HCS }\end{array}$ \\
\hline
\end{tabular}

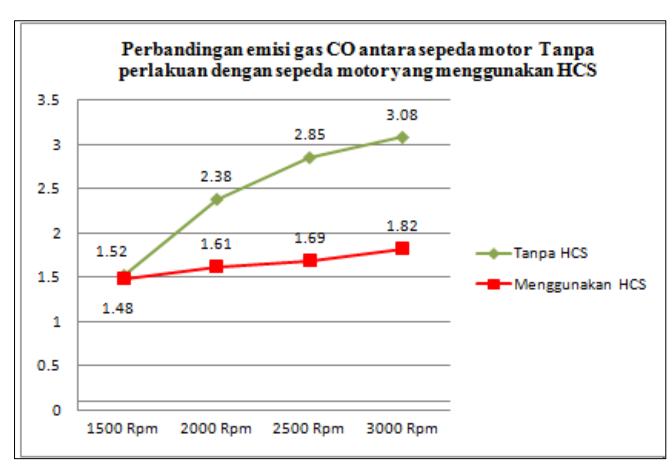

Dari data diatas maka perbandingan pengujian emisi gas buang tidak memakai alat HCS yaitu $40 \%$, sedangakan pemakain alat HCS $37 \%$. sehingga dapat disimpulkan penggunaan alat HCS berpengaruh terhadap emisi gas buang pada sepeda motor untuk menurunkan kadar CO 3\% dari sebelum pemakain alat HCS.

\section{Kesimpulan}

Setelah dilakukan pengujian performa mesin sepeda motor supra $X$ menggunakan alat dynojet maka Hidrocarbon Crack System berpengaruh 
terhadap torsi dan daya sepeda motor. Sedangkan pengujian bahan bakar menggunakan alat hcs didapat perbedaan jarak tempuh sebelum dan setelah memakai Hidrocarbon Crack System sebesar $10 \mathrm{~km}$.

Hasil pengujian emisi gas buang menunjukan bahwa penggunaan HCS dapat menurunkan emisi gas $\mathrm{CO}$ sebesar $40 \%$. Untuk emisi gas HC mengalami penurunan sebesar $37 \%$, sedangkan untuk emisi gas buang $\mathrm{CO} 2$ mengalami peningkatan sebesar $12.98 \%$. Maka di simpulkan HCS dapat menghemat bahan bakar, dan menurunkan $\mathrm{CO}$ pada kendaraan.

\section{Daftar Pustaka}

[1] Abdillah, F. dan Sugondo. 2014. Prototipe Alat Penghemat Bahan Bakar Mobil Menggunakan Metode Hydrocarbon Crack System untuk Menghemat Bahan Bakar dan Mengurangi Emis Gas Buang.

[2] Arifin, Zainal dan Sukoco. 2009. Pengendalian Polusi Kendaraan. Bandung: Alfabeta

[3] Ghazal, Osama. 2013. A Theoretical Study of the SI Engine Performance Operating with Different Fuels. International Journal of Mechanical, Aerospace, Industrial, Mechatronic and Manufacturing Engineering, 7/12: 2526-2529.

[4] Granlund, Moa Z. 2015. Fuel Reforming for Hydrogen Production in Heavy- Duty Vehicle Applications. Doctoral Thesis in Chemical Engineering. Stockholm: KTH School of Chemical Science and Engineering, Sweden.

[5] Hairuddin, A.A., A.P. Wandel dan T.Yusaf. 2014. An Introduction to A Homogeneous Charge Compression Ignition Engine. Journal of Mechanical Engineering and Sciences (JMES), $\quad 7 /-: 1042-1052 . \quad$ e-ISSN: 2231-8380.

[6] Ikhsan, Muadi. 2010. Pengaruh Jumlah Katalisator Pada Hydrocarbon Crack
System (Hcs) dan Jenis Busi Terhadap Daya Mesin Sepeda Motor Yamaha Jupiter Z Tahun 2008. Jurusan Pendidikan Teknik Kejuruan. FKIP-UNS.

[7] Iyer, Narayan V. 2012. A Technical Assessment of Emissions and Fuel Consumption Reduction Potential From Two and Tree Wheelers in India. Prepared for: the International Council on Clean Transportation. Washington DC. 